\title{
SHOWING SELECTED GEOLOGY AND PHOSPHATE RESOURCES OF THE JOHNSON CREEK QUADRANGLE, CARIBOU COUNTY, IDAHO By Pamela Palmer, ${ }^{1}$ Warren Barrash, ${ }^{1}$ Pamela Dunlap Derkey, ${ }^{1}$

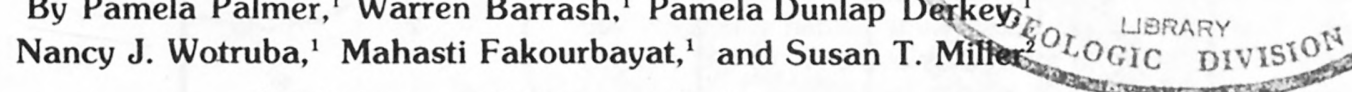 \\ ${ }^{1}$ Idaho Bureau of Mines and Geology \\ ${ }^{2}$ Bureau of Land Management
}

\section{INTRODUCTION \\ PURPOSE OF INVESTIGATION}

This report summarizes information on the thickness, grade, lateral continuity, phosphate resources, and ownership of phosphate-bearing units in the Meade Peak Phosphatic Shale Member of the Phosphoria Formation in the Johnson Creek quadrangle. This report is one of a series of quadrangle reports prepared by the Idaho Bureau of Mines and Geology under U.S. Geological Survey costsharing contract \#14-08-0001-17925 to calculate phosphate resources in southeastern Idaho (fig. 1).

\section{ACKNOWLEDGMENTS}

The project was supervised by Bill Bonnichsen of the Idaho Bureau of Mines and Geology and Peter Oberlindacher of the Bureau of Land Management. Alumet, Monsanto Chemical Company, and J.R. Simplot company provided their geologic maps and drill-hole and trench data on the understanding that this confidential information would be used only in a regional analysis of phosphate resoures. We wish to thank the College of Mines and Earth Resources and the College of Forestry, University of Idaho, for the use of their cartographic facilities.

\section{METHODS OF INVESTIGATION}

The Johnson Creek quadrangle phosphate resource maps are based on published and unpublished data from university, industry, State, and Federal sources.

The interpretation of the structure of the Meade Peak Phosphatic Shale Member in the subsurface is based on cross sections constructed from U.S. Geological Survey and phosphate company geologic maps, cross sections, and drill hole and trench logs, supplemented by discussions with Bureau of Land Management and company geologists. Phosphate rock thickness and $\mathrm{P}_{2} \mathrm{O}_{5}$ assay values are used from only those drill holes and trenches whose locations can be accurately plotted for elevation and land coordinates. Structure contours and overburden isopachs drawn on the stratigraphic top of the Meade Peak are extended 600 feet along strike from the last known exposure of the Phosphoria Formation and are extrapolated to a depth of 1,500 feet. Phosphate resources of the Meade Peak are calculated for three categories of overburden thickness: 0 to 300 feet, 300 to 600 feet, and 600 to 1,500 feet (fig. 2).

Identified phosphate resources (U.S. Bureau of Mines and U.S. Geological Survey, 1980) are computed for the upper and lower phosphate units of the Meade Peak (fig. $3)$. Resource tonnages were determined according to the method used by Montgomery and Cheney (1967, p. 41) and Oberlindacher and Hovland (1979, p. 7). For the Johnson Creek quadrangle, ninety resource blocks (not shown on the map sheets) were constructed based on structural similarities. The volume (V) of phosphate re- source in each block is calculated by multiplying the true area of the stratigraphic top of the Meade Peak by the cumulative average thickness ( $t$ ) of the upper and lower phosphate units. The true area is the planimetered map surface area (A) of each block multiplied by the secant of the average dip (d) of the Meade Peak (fig. 4):

(1) $\mathrm{V}=$ At $(\sec \mathrm{d})$

Resource tonnages $(\mathrm{R})$ are calculated by multiplying the volume $(\mathrm{V})$ of phosphate resource by the average density $(\rho)$ of the phosphate rock:

(2) $\mathrm{R}=\mathrm{V}_{\rho}$

An average density of 0.0787 short tons per cubic foot, derived from Oberlindacher and Hovland's (1979) average density value of 2.52 metric tons per cubic meter, is applied to convert the volume of phosphate resource (calculated in cubic feet) to short tons of phosphate resource (sheets 2 and 3 ).

Thickness, phosphate content, and stratigraphic position are the three factors that determine whether a "sampling interval" is included within the phosphate units to calculate resource tonnages. A "sampling interval" is a rock sample of known thickness and phosphate content, as derived from a drill hole or trench log. The Meade Peak is subdivided into five informally named units for this report based on Hale's (1967) subdivisions of a typical section in the upper Dry Valley area, Caribou County, Idaho (fig. 3). These units are, from bottom to top: the lower waste, the lower phosphate, the middle waste, the upper phosphate, and the upper waste. The only units considered in the resource calculations in this report were the lower and upper phosphate units (fig. 3). Isolated minor phosphorite beds in the waste units are excluded from consideraion.

The following guidelines used in this report to define phosphate units are based on Montgomery and Cheney (1967), Oberlindacher and Hovland (1979), and generally accepted phosphate mining practices in southeastern Idaho:

(1) The upper and lower boundaries of the phosphate units are defined by the uppermost and lowermost sampling intervals that are 1 foot or more thick and contain at least 16 percent $\mathrm{P}_{2} \mathrm{O}_{5}$, except where adjoining sampling intervals less than 1 foot thick with 16 or more percent $\mathrm{P}_{2} \mathrm{O}_{5}$ are added together to meet the 1 -foot thickness requirement. Within a phosphate unit, all sampling intervals with 16 or more percent $\mathrm{P}_{2} \mathrm{O}_{5}$ are included in the resource calculation regardless of thickness.

(2) Within the phosphate units, sampling intervals and sequences of contiguous sampling intervals containing less than 16 percent $\mathrm{P}_{2} \mathrm{O}_{5}$ and measuring at least 2 feet thick are excluded from the resource calculation. 


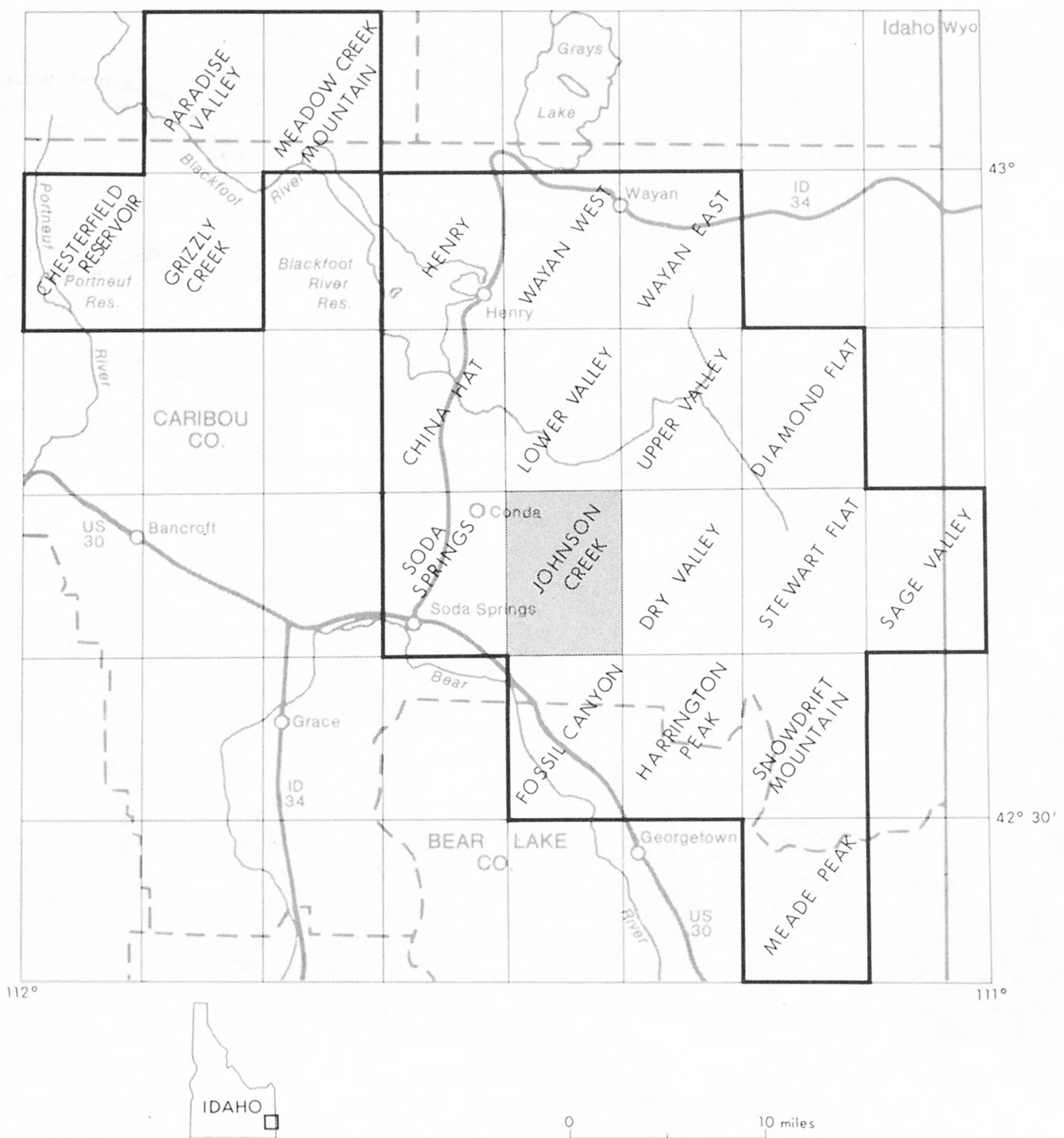

FIGURE 1.-Index map showing location of southeast Idaho phosphate area and Johnson Creek quadrangle (shaded).

(3) Within the phosphate units, isolated sampling intervals less than 2 feet thick with less than 16 percent $\mathrm{P}_{2} \mathrm{O}_{5}$ are included in the resource calculation.

The boundaries of all phosphate open-pit mines and test pits were identified from false-color aerial photographs taken in 1979 by the U.S.Geological Survey.

The locations of titles to surface and phosphate rights were obtained for Federal lands from the U.S. Bureau of Land Management's leasable mineral and master title plats and for State lands from the Idaho Department of Lands' land plats. These sources also were used to locate Federal phosphate leases, Preference Right Lease Applications (PRLAs), Known Phosphate Leasing areas (KPLAs), State phosphate leases, and patented phosphate claims. Titles to surface and phosphate rights on private land are from both the Federal and State plats. Private phosphate leases, leases on land with private title to both surface and phosphate rights, are not shown.

LOCATION AND TOPOGRAPHY

The Johnson Creek quadrangle is about 5 miles east of Soda Springs, Idaho (fig. 1). The quadrangle boundary includes parts of Tps. 8 and 9 S., Rs. 42 and 43 E., Boise Principal Meridian. Most of the area is accessible by gravel-surfaced roads.

Major topographic features in the quadrangle include the northwest-trending Aspen Range, Slug Creek Valley, and Schmid Ridge. Slug Creek, Trail Creek, Johnson Creek, and their tributaries drain the area. Altitudes range from 6,130 feet at the west end of South Sulphur Canyon to 8,302 feet on Sulphur Peak. 


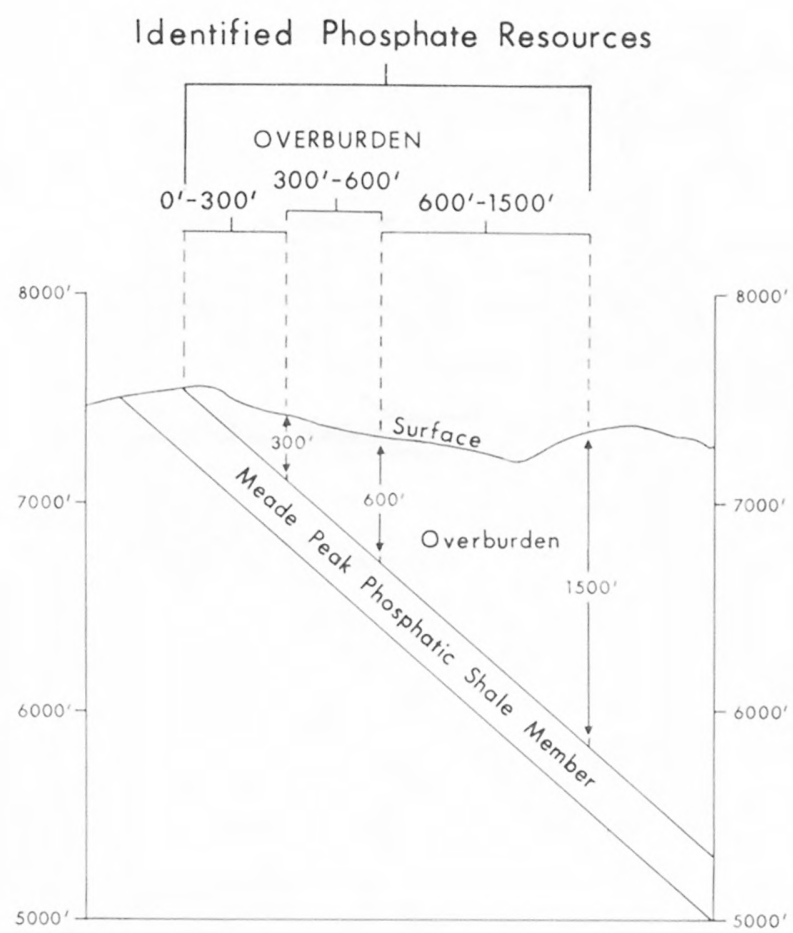

FIGURE 2.-Diagrammatic cross section showing identified phosphate resources for the Meade Peak Phosphatic Shale Member of the Phosphoria Formation.

\section{FEDERAL LAND STATUS}

Six combinations of titles to surface and phosphate rights occur in the Johnson Creek quadrangle as shown on sheet 3: (1) Federal phosphate on Federal surface, (2) Federal phosphate on State surface, (3) Federal phosphate on private surface, (4) State phosphate on State surface, (5) State phosphate on private surface, and (6) private phosphate on private surface. The Federal government holds phosphate title to 79 percent and surface title to 50 percent of the land in the Johnson Creek quadrangle. As of August 1980, about 14 percent of the Federal phosphate title was leased.

\section{GEOLOGY OF THE MEADE PEAK PHOSPHATIC SHALE MEMBER \\ OF THE PHOSPHORIA FORMATION STRATIGRAPHY}

In Idaho, the Phosphoria Formation of Permian age disconformably overlies the Park City Formation of Permian age and Wells Formation of Pennsylvanian and Permian age and is uncomformably overlain by the Dinwoody Formation of Triassic age (McKevey and others, 1959; Peterson, 1980). The Phosphoria grades northward into the Shedhorn Sandstone in south-central Montana and northwestern Wyoming, and southward and eastward into the Park City Formation in northeastern Utah and west-central Wyoming (McKelvey and others, 1959). The Park City Formation, a carbonate sequence, in turn grades eastward into the Goose Egg Formation, a red-bed evaporite sequence (McKelvey and others, 1959).

The Phosphoria Formation is subdivided into six members, four of which are recognized at the type locality at Phosphoria Gulch, Bear Lake County, Idaho (McKelvey and others, 1959). The four members are, from bottom to top: the Meade Peak Phosphatic Shale Member, the
Rex Chert Member, the cherty shale member, and the Retort Phosphatic Shale Member. The other two members are the lower chert member, which is laterally continuous with the Meade Peak, and the Tosi Chert Member, which is laterally continuous with the upper part of the Retort and with the cherty shale member (McKelvey and others, 1959 , p. 21). As discussed in the "Methods of Investigation" section, the Meade Peak has been subdivided into five informally named units based on lithology and $\mathrm{P}_{2} \mathrm{O}_{5}$ content (fig. 3). The two phosphate units defined by Hale (1967; fig. 3, this report) consist of interbedded phosphorite, mudstone, and limestone. The waste units consist of interbedded shale, mudstone, siltstone, and thin phosphorite beds. The base of the Meade Peak is characterized by a thin phosphorite bed containing abundant fish scales, bones, and small nodules (McKelvey and others, 1959. p. 23) known as the fish-scale marker bed (Hale, 1967). The top of the Meade Peak is not as well defined. In southeastern Idaho, the uppermost bed is either a thin, nodular phosphorite, commonly containing gastropods resembling Omphalotrochus, or a thin, soft mudstone locally overlying the nodular phosphorite (McKelvey and others, 1959, p. 23).

In the Johnson Creek quadrangle, the Meade Peak Phosphatic Shale Member ranges from 100 to 200 feet in thickness, determined from selected drill-hole and trench data. Much of this variation in thickness may be the result of weathering, deformation, and faulting. There is no apparent systematic trend of thinning or thickening along strike; rather, the unit appears to pinch and swell locally. Similar local thickness variations occur on a smaller scale for phosphate rock in the upper and lower phosphate units of the Meade Peak. Within the quadrangle, the Meade Peak crops out discontinuously along strike about 28 miles. Based on available drill hole and trench data, the phosphate rock within the Meade Peak in the Johnson Creek quadrangle averages 39 feet in thickness with a weighted average of 23.9 percent $\mathrm{P}_{2} \mathrm{O}_{5}$. Detailed stratigraphic sections and semiquantitative spectrographic determinations of the Meade Peak have been published by the U.S. Geological Survey for trenches 1206 and 1209 in the quadrangle (McKelvey and others, 1953).

\section{STRUCTURE}

Structure is complex in the Johnson Creek quadrangle. The Trail Creek syncline and Aspen Range anticline, two major folds in the quadrangle, are obscured by numerous faults and minor folds. The north-northwest trending Trail Creek syncline runs the length of the western and central parts of the quadrangle, becoming less defined to the south. Two smaller, transverse folds at the head of Johnson Creek, along with numerous faults in the vicinity of South Sulphur Canyon, help to obscure the southern part of the syncline. The Meade Peak is continuous along the entire west limb of the syncline, with variable normal dips to the east, averaging 50 degrees in the north and shallowing to an average of 25 degrees in the south (Sheet 1 , section $\left.A-A^{\prime}\right)$. The Meade Peak in the vicinity of the two transverse folds has a much shallower dip, at times nearing horizontal (Sheet 1 , section $B-B^{\prime}$ ). The Aspen Range anticline, also trending north-northwest, lies to the east of the Trail Creek syncline. Bounded on the west by a major fault, the Aspen Range anticline is concealed by numerous longitudinal faults, minor folds, and some transverse faults. The Meade Peak as mapped to the west of the Aspen Range anticline has a gentle dip and lies close to the surface. 


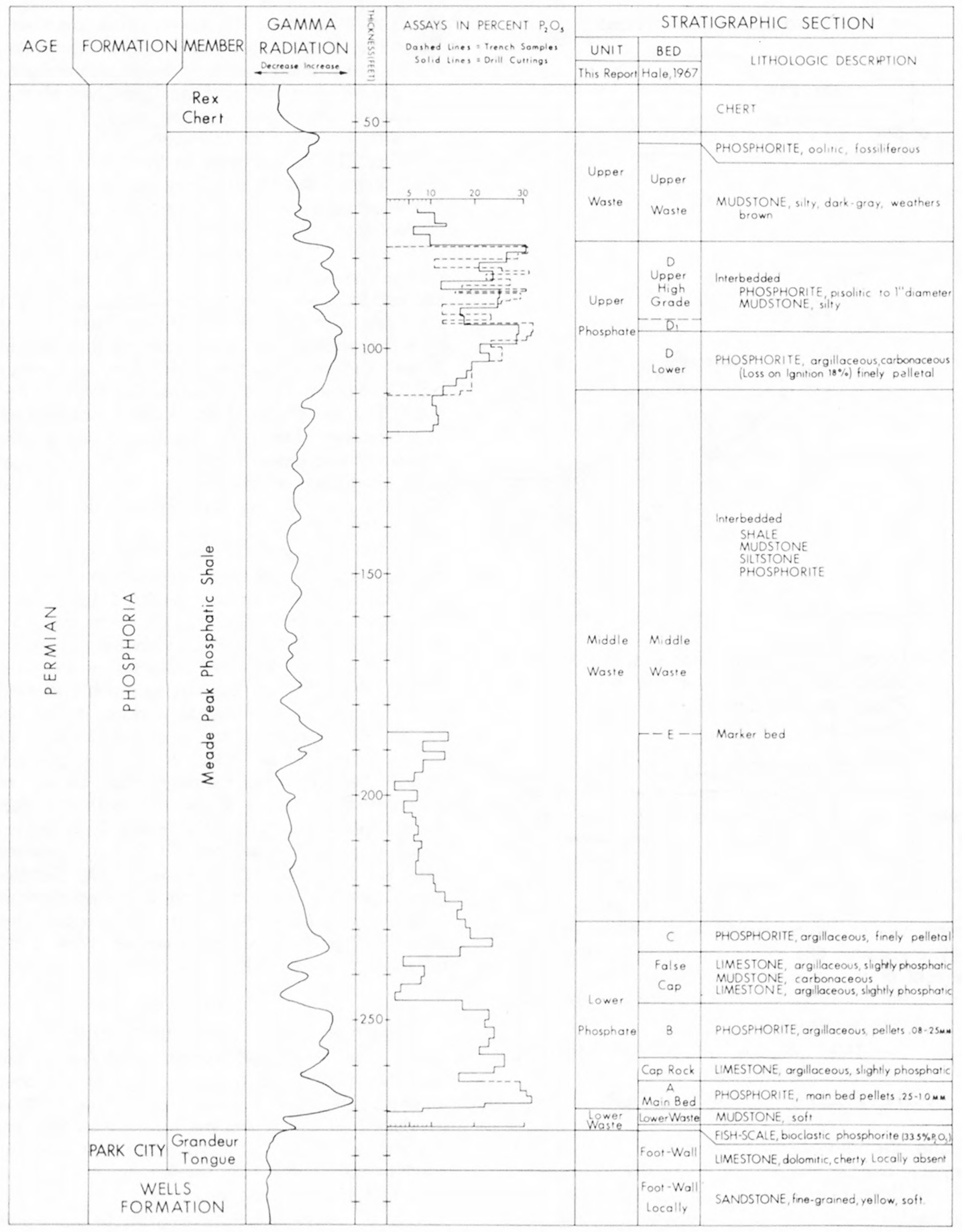

FIGURE 3.- Typical Permian section, upper Dry Valley area, Caribou County, Idaho (from Hale, 1967).

The largest faults in the quadrangle are generally north-trending normal faults, although there are two large tear faults in the north half of the quadrangle (Gulbrandsen and others, 1956, p. 16). One of the large, normal faults occurs along the western border of the quadrangle and is associated with overturned folds. This area, between Wood Canyon and Middle Sulphur Canyon, is not included in phosphate resource estimates in this report because the complex nature of the faults and folds makes reconstructions of the phosphate beds highly questionable
(Sheets 1 and 2). In the south central part of the quadrangle some additional areas were left out of resource calculations because of exremely poor control or conflicting data. Smaller faults, both in length and displacement, occur throughout the quadrangle, but are particularly abundant in the northeast quarter and also in the southern half of the quadrangle. The complex of faults in the northeast quarter of the quadrangle breaks up the Meade Peak into many small blocks (Sheet 1 , section $C-C^{\prime}$ ). Dips of the Meade Peak generally range from 5 degrees to 45 


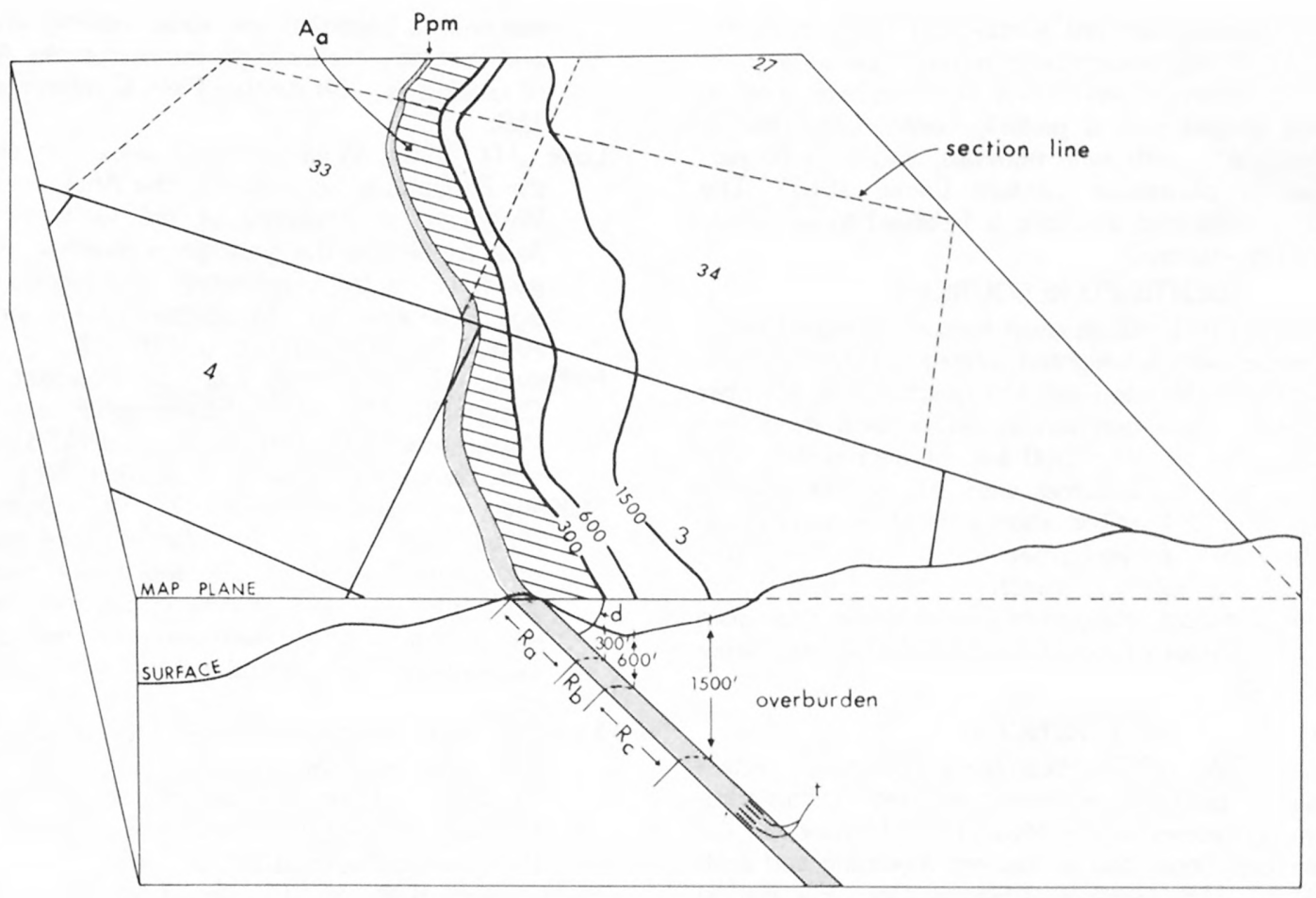

Explanation and sequence of calculations:

(1) $\quad \mathrm{V}_{\mathrm{a}}=\mathrm{A}_{\mathrm{a}} \mathrm{t}(\mathrm{sec} \mathrm{d})$

(2) $\quad \mathrm{R}_{\mathrm{a}}=\mathrm{V}_{\mathrm{a}} \rho$

$\mathrm{V}_{\mathrm{a}}=$ volume of resources under less than $300^{\prime}$ of overburden

$A_{a}=$ measured map surface area of resources under less than $300^{\prime}$ of overburden

$\mathrm{t}=$ cumulative average thickness of the upper and lower phosphate units

$\mathrm{d}=$ average dip of the Meade Peak Phosphatic Shale Member of the Phosphoria Formation

$R_{a}=$ resources under less than $300^{\prime}$ of overburden

$R_{b}=$ resources under $300^{\prime}$ to $600^{\prime}$ of overburden

$\mathrm{R}_{\mathrm{c}}=$ resources under $600^{\prime}$ to $1500^{\prime}$ of overburden

$\rho=$ average density of phosphate rock $=0.0787$ short tons per cubic foot

FIGURE 4.-Block diagram showing method of calculating phosphate resources.

degrees and the fault displacement is usually small, so much of the phosphate resource in this area has less than 300 feet of overburden (Sheet 2).

\section{MINERALOGY AND GEOCHEMISTRY}

Altered phosphorite within the Meade Peak Phosphatic Shale Member consists, for the most part, of mediumgrained, rounded pellets composed of microcrystalline apatite aggregates (Emigh, 1958; Gulbrandsen, 1966). The typical Meade Peak phosphorite is approximately 80 percent apatite, 10 percent quartz, 5 percent muscovite-illite, 2 percent organic matter, 1 percent dolomite-calcite, 1 percent iron oxide, and 1 percent other components (Gulbandsen, 1966).

According to Gulbrandsen (1966), the apatite is a fluorapatite, $\mathrm{Ca}_{5}\left(\mathrm{PO}_{4}\right)_{3} \mathrm{~F}$, with sodium substituting for calcium, and carbonate and sulfate substituting for the phosphate radical. Also substituting, to a lesser extent, for calcium are strontium, uranium, thorium, yttrium, lanthanum, neodymium, and ytterbium. Pelletal and oolitic phosphate beds with greater than 31 percent $\mathrm{P}_{2} \mathrm{O}_{5}$ and greater than 3 feet in thickness generally contain 0.01 to 0.02 percent uranium (McKelvey and Carswell, 1967). Several elements-arsenic, cadmium, chromium, copper, molybdenum, nickel, antimony, selenium, vanadium, zinc, and silver(?) - occur in the organic fraction of the phosphorite (Gulbrandsen, 1966).

Vanadium occurs within several shale and mudstone beds of the Meade Peak. One zone of economic interest (about 5 to 10 feet below the upper phosphate unit) averages 4 feet in thickness and 0.7 percent vanadium pentoxide, and is associated with small amounts of selenium, molybdenum, zinc, nickel, cobalt, titanium, and cadmium (Love, 1967). Through electron microprobe studies of samples from thin beds of vanadium-rich shale and mudstone in the phosphate-rich zones, Desborough (1977) found vanadium in or associated with organic material in leached samples; chromium in a 10-A mica in unleached phosphate nodule samples; zinc and cadmium in sphalerite; silver associated with the organic material and not as a silver sulfide phase; selenium in pyrite; sulfur in pyrite, sphalerite, and the organic material; titanium in titanium dioxide; and molybdenum in powellite.

The Meade Peak has been altered and naturally ben- 
eficiated by postdepositional weathering (supergene enrichment). Unaltered phosphorite is hard, carbonaceous, calcareous to dolomitic, and lower in phosphate content, whereas the altered rock is partially consolidated, low in organic matter and carbonate minerals, and 3 to 10 percent higher in phosphate content (Hale, 1967). The weathered-unweathered interface is believed to be highly irregular and gradational.

\section{IDENTIFIED RESOURCES}

A total of 1,054 million short tons of identified phosphate resources with a weighted average of 23.9 percent $\mathrm{P}_{2} \mathrm{O}_{5}$ is within the Meade Peak Phosphatic Shale Member in the Johnson Creek quadrangle: 547 million short tons of resources with less than 300 feet of overburden, 212 million short tons of resources with 300 to 600 feet of overburden, and 294 million short tons of resources with 600 to 1,500 feet of overburden. ${ }^{1}$ Thickness and $\mathrm{P}_{2} \mathrm{O}_{5}$ data from 23 drill hole and trench logs were used to calculate these resources. Resources are based on data from the nearest drill holes or trenches situated along the same structural feature.

\section{REFERENCES}

Desborough, G.A., 1977, Preliminary report on certain metals of potential economic interest in thin vanadium-rich zones in the Mead Peak Member of the Phosphoria Formation in western Wyoming and eastern Idaho: U.S. Geological Survey Open-File Report 77-341, $27 \mathrm{p}$

Emigh, G.D., 1958, Petrography, mineralogy, and origin of phosphate pellets in the Phosphoria Formation: Idaho Bureau of Mines and Geology Pamphlet 114.

Gulbrandsen, R.A., 1966, Chemical composition of phosphorites of the Phosphoria Formation: Geochimica et Cosmochimica Acta, v. 30, p. 769-778.

Gulbrandsen, R.A., McLaughlin, K.P., Honkala, F.S., and Clabaugh, S.E., 1956, Geology of the Johnson Creek Quadrangle, Caribou County, Idaho: U.S. Geological Survey Bulletin 1042-A, 23 p.

Hale, L.A., 1967, Phosphate exploration using gammaradiation logs, Dry Valley, Idaho, in Anatomy of the western phosphate field, a guide to the geologic oc- curence, exploration methods, mining engineering, and recovery technology: Intermountain Association of Geologists, 15h Annual Field Conference, p. 147159.

Love, J.D., 1967, Vanadium and associated elements in the Phosphoria Formation in the Afton area, western Wyoming, in Anatomy of the western phosphate field, a guide to the geologic occurrence, exploration methods, mining engineering, and recovery technology: Intermountain Association of Geologists, 15th Annual Field Conference, p. 115-118.

McKelvey, V.E., Armstrong, F.C., Gulbrandsen, R.A., and Campbell, R.M., 1953, Stratigraphic sections of the Phosphoria Formation in Idaho 1947-1948, pt. 2: U.S. Geological Survey Circular 301, 58 p.

McKelvey, V.E., and Carswell, L.D., 1967, Uranium in the Phosphoria Formation, in Anatomy of the western phosphate field, a guide to the geologic occurrence, exploration methods, mining engineering, and recovery technology: Intermountain Association of Geologists, 15th Annual field Conference, P. 119 123.

McKelvey, V.E., Williams, J.S., Sheldon, R.,P., Cressman, E.R., Cheney, T.M., and Swanson, R.W., 1959, The Phosphoria, Park City, and Shedhorn Formations in the western phosphate field: U.S. Geological Survey Professional Paper 313-A, p. 1-47.

Montgomery, K.M., and Cheney, T.M., 1967. Geology of the Stewart Flat quadrangle, Caribou County, Idaho: U.S. Geological Survey Bulletin 1217, 63 p.

Oberlindacher, Peter, and Hovland, R.D., 1979, Geology and phosphate resources of the Hawley Creek area, Lemhi County, Idaho: U.S. Geological Survey OpenFile Report 79-1283.

Peterson, J.A., 1980, depositional history and petroleum geology of the Permian Phosphoria, Park City, and Shedhorn Formations, Wyoming and southeastern Idaho: U.S. Geological Survey Open-File Report 80667, $42 \mathrm{p}$.

U.S. Bureau of Mines and U.S. Geological Survey, 1980, Principles of a resource/reserve classification for minerals: U.S. Geological Survey Circular 831, 5 p. 
